\title{
Assessment of the ecological state of pastures and methods of their improvement, adapted to the conditions of global climate change
}

\author{
Tolibjon Mukimov*, Muhtor Nasirov, Bakhtiyor Mardonov, Tashpulot Rajabov, and \\ Mahmud Muminov \\ Samarkand State University, 140104, Samarkand, Uzbekistan
}

\begin{abstract}
The article provides information on the state of natural pastures and methods for improving degraded pastures by overseeding perennial drought-resistant forage crops using resource-saving technologies adapted to the conditions of global climate change.
\end{abstract}

Keywords: natural pastures, climate change, drought-resistant forage

\section{Introduction}

According to its natural and climatic conditions, the territory of Uzbekistan belongs to the zone of continental arid climate. The average amount of precipitation in the desert part of Uzbekistan is $100-200 \mathrm{~mm}$, in the mountainous part of the country there is $400-800 \mathrm{~mm}$ of precipitation per year or more. Overgrazing, deforestation, and plowing of virgin lands in places have led to severe degradation of vegetation, erosion, decreased productivity and soil salinity. High sensitivity of desert and mountain ecosystems to climate change combined with natural and anthropogenic desertification processes make Uzbekistan one of the countries in the world with the most serious land degradation.

Natural pastures, amounting to more than 23 million hectares, are the main source of life support and well-being of the population living here, are characterized by relatively low productivity $(0.25-0.32 \mathrm{t} / \mathrm{ha})$ and are an ecologically fragile ecosystem. Due to the unsystematic, irrational use of pasture ecosystems, degradation of vegetation cover is observed on an area of more than $40 \%$ of the territories. In most cases, animals are provided with purchased feed, the profitability of farms engaged in animal husbandry is very low, at the same time, there is a tendency for a constant increase in the number of livestock in dekhkan farms. [1,2]

In contrast to the sandy desert, in the territories of adyrs and gypsum desert, the number of grazed animals is large; there is only about 1 hectare of pastures per conventional head. All this constitutes a load 3-4 times greater than the norm, which leads to an intensification of degradation processes, a decrease and depletion of vegetation biodiversity. This unsatisfactory state is formed due to the irrational and unsystematic use of pastures, cutting of bushes, and overloading of pastures. The main reasons for this unfavorable situation are that $85 \%$ of rain-fed land use is located in the desert and semi-desert natural and climatic zone of the country, which is more prone to land degradation. Global climate change, a decrease in precipitation, and more frequent droughts have negatively affected the efficiency

*Corresponding author: mukimovt56@mail.ru 
of rain fed agriculture, pasture and forest land use. Mass cutting of trees and shrubs by the local population for economic needs due to the insufficient availability of other sources of energy also contribute to the degradation of natural lands and the loss of climax, normally functioning cenoses. The continuation of the use of degraded pastures as part of forestry, leads to a reduction in the area of forests, which in turn is the reason for the increased aridization of the regions. The crisis in the Aral Sea basin accordingly has a significant negative impact. $[3,4]$

Purpose of the study. The main purpose of the research was a comprehensive study of the state of natural pastures and approbation of methods for improving degraded pastures by sowing perennial drought-resistant forage crops resistant to climate change.

\section{Materials and research methods}

Determination of the state of types of pastures and pasture differences, the degree of degradation of pastures was carried out on the basis of identifying the dominant species or group of species [5-9]. The following features were taken into account:

- The influence of domestic animals on herbaceous vegetation and soil cover - the degree of grazing and trampling, the presence of animal paths;

- Signs of a negative change in the composition and structure of vegetation - a decrease in the percentage of projective vegetation cover, a decrease in the abundance and inhibited state of forage species, the predominance of xerophytes and ephemerals, an increase in the presence of non-food, poisonous, weed plant species in the grass stand (the more the vegetation is disturbed, the higher the abundance of these species, up to the complete displacement of forage plants).

- Impact of livestock grazing on tree and shrub vegetation - completeness of stands, degree of crown damage, number and condition of undergrowth; - The presence of traces of plowing or fire and their age; - The presence of traces of felling or haymaking; - The presence of endemic and rare species and their condition (normal or depressed).

\section{Results and discussion}

The main way to ensure the stable development of animal husbandry and environmental protection is the introduction of effective technologies for improving pastures, allowing them to increase their productivity by 3-4 times, the development and implementation of a system for the rational use of artificial and natural fodder lands, the intensification of forage production by creating hayfields, the search for alternative sources of income for local population.

Recommended technologies adapted to the conditions of global climate change for different zones:

Sandy desert. Pasture animal husbandry in Uzbekistan is diversified in structure and is deployed in regions with low natural resource potential. The vegetation cover under these conditions is sparse, consists of ephemeral and semi-shrub vegetation, adapted to a hot and dry climate. [10-13]

An effective method for improving natural pastures in the desert zone is pasture protection belts, which create more favorable conditions for the growth and development of native vegetation (soften the microclimate, promote the accumulation of soil moisture, reduce the speed of winds, and protect the soil from deflation). Pasture protection belts are laid 10-25 m wide from large shrubs (Haloxylon, Salsola paletzkiana and Calligonum), with a density of 600-1200 pcs/ha. Natural pastures are left between the strips. Saplings are planted in furrows 
$1 \mathrm{~m}$ wide, in the same furrows, in addition to obtaining guaranteed seedlings, seeds of Haloxylon aphyllumare sown.

The technology provides benefits after 3-4 years, and farmers can distribute seeds and expand the area under crops at no additional cost. The technology is low-cost, so the result obtained in comparison with investments is positive already in the short term. In the system of technology for the restoration of degraded lands, Haloxylon, Salsola paletzkiana and Calligonum species are recommended Haloxylon aphyllum (Minkw) Iljin, is characterized by a high and stable yield of forage mass, long productive longevity (25-35 years). In multicomponent agrocenoses, it significantly reduces the wind speed, retains snow, increasing the relative humidity of the air, thereby creating a special microclimate that favorably affects the growth and development of plants in the lower tiers. The yield of airdry fodder mass is $1.34-1.26 \mathrm{t} / \mathrm{ha}$, seeds $-50-130 \mathrm{~kg} / \mathrm{ha}$. $100 \mathrm{~kg}$ of dry air contains 45.5 feed units.

Haloxylon persicum Bge.is a shrub from the family of Chenopodiacea, 3-4 m high, with a thick, gnarled, gray-brown trunk. It develops a powerful and deeply penetrating root system that uses moisture at a depth of 3-20 m. Haloxylon persicum is a white valuable desert plant that provides food for sheep and camels. It has an important meliorative value as an excellent sand strengthening agent. Sheep willingly eat it in autumn and winter, weakly in spring and summer. It is well eaten by camels all year round. Nutritional value of feed 52 feed units per $100 \mathrm{~kg}$ of dry weight.

Under natural conditions, the yield of the forage mass is small, -0.2-0.4 t/ ha of air-dry forage. Haloxylon persicumis a promising plant for creating pasture agrophytocenoses in sandy deserts.

Salsola paletzkiana Litv. - shrubs from the Chenopodiacea family, 3-5 m high, are typical psammophytes, in nature they are distributed mainly in a sandy desert, often landscape species. $100 \mathrm{~kg}$ of air-dry food, depending on the seasons of the year, contains from 33 to 45 feed units. The root system is of a universal type. Individual fodder productivity ranges from 3.5-6.2 kg per bush, and in the structure of fodder yield a high proportion (up to $72 \%$ ) belongs to the seed fraction.

Calligonum are shrubs up to 2-3 meters high, belonging to the Polygonaceae family. Among the species belonging to this family, there are species with upright stems Calligonum caput-medusae or branched Calligonum microcarpa, Calligonum setosum.

All Calligonum species are valuable forage plants for sheep, goats and camels. $100 \mathrm{~kg}$ of air-dry food contains 71.8 feed units. Calligonum species live 15-20 years and form high yields of forage mass. Under crop conditions, the yield is $0.9-0.16 \mathrm{t} / \mathrm{ha}$. Calligonum species are promising plants for strengthening mobile sands.

Foothill semi-desert. Pasture areas of the foothill zone are devoid of semi-shrub and shrub vegetation. Livestock farms annually harvest and purchase livestock for the winter (about 30$40 \%$ ) in a very large volume of rough and concentrated feed, which significantly reduces the efficiency of animal husbandry, contributes to an increase in the cost of production and a decrease in the profitability of animal husbandry, in dry years, a sharp reduction in the number of livestock. [14]. In general, there is usually an acute shortage of forage in the foothill pastures in the autumn-winter season. On this type of pasture, plants such as Carex, Poa bulbosa, and other ephemeroids grow.[4, 15-16]

The average annual yield of pastures is low $-0.25-0.3 \mathrm{t} / \mathrm{ha}$. Weeds, poorly eaten plants grow in large numbers on pastures. For the enrichment and restoration of degraded pastures, over seeding of seeds of perennial drought-resistant forage species is recommended. [17]. In 2016, on an area of 50 hectares in Zamin District, a UNDP project sowed seeds of 6 types of forage crops. [18] The coverage area of pastures with inter-strip spaces was 450 hectares. As a result of the fencing, many species of forage plants appeared in this area i.e. increased biodiversity. Studies have shown that one-time costs of a farm for improving pastures in 2-3 
years fully pay off. These pastures have been used for 20-25 years, but with proper use, i.e. grazing $70-75 \%$ of the plant mass and the possibility of sowing plants, they can be used for a long time. The following types of perennial drought-resistant forage crops were sown on the plowed fields:

Aellenia subaphylla (C.A. Mey) Aellen, a shrub $70 \mathrm{~cm}$ high - $2.0 \mathrm{~m}$ from the Chenopodiaceae family. The root system is powerful, deeply penetrating into the soil of a universal type. Productive longevity 15 years. It is very drought and salt tolerant, resistant to diseases and pests, to intensive grazing. The growing season is 240 days. The yield of dry fodder mass is 1.0-1.5 t/ ha, seeds are $0.2-0.3 \mathrm{t} /$ ha. $100 \mathrm{~kg}$ of hay contains 42 feed units, up to $20 \%$ protein and $2.5 \%$ fat. Recommended for cultivation on chestnut, gray earth, brown and sandy soils of low and medium salinity, with an amount of atmospheric precipitation of 80 to $400 \mathrm{~mm}$.

Atriplex undulata is a perennial dwarf shrub from the Chenopodiaceae family. Plant height is $100-120 \mathrm{~cm}$. It has a long growing season of 250-280 days. The yield of the air-dry fodder mass of Atriplex undulata forms 1.2-1.5 t/ ha of fodder mass and 0.25-0.35 $\mathrm{t} /$ ha of seeds.

Ceratoides eversmanniana Botsch, et Ikonn. Is a semi-shrub from the family of Chenopodiaceae, 65-85 cm high. Differs in high resistance to trampling (pasture tolerance), well eaten by farm animals, especially Karakul sheep and goats. $100 \mathrm{~kg}$ of feed contains 41 43 feed units. The growing season is $230-240$ days. The yield of dry fodder mass is $1.12-1.25$ $\mathrm{t} / \mathrm{ha}$, the yield of seeds is $0.12-0.17 \mathrm{t} / \mathrm{ha}$. Productive longevity - 17-23 years.

Kochia prostrata (L) schrad. Is a semi-shrub from the family of the Chenopdiaceae, 30$75 \mathrm{~cm}$ high, in culture it often reaches $60-90 \mathrm{~cm}$ higher. Kochia is an ecologically plastic plant. It develops a powerful deeply penetrating (up to 5-6 m) root system of a universal type, uses the moisture of a large volume of soil. It is a drought-resistant plant that economically consumes moisture for transpiration, is demanding for heat and light, and withstands medium soil salinity. Productive longevity is $15-20$ years. The maximum yield of forage mass and seeds in culture is observed at 3-4 years of age. [19-20]

Artemisia is a semi-shrub from the Asteraceae family, 20-60 cm high. On pastures, life expectancy is $12-25$ years. The growing season is 240-280 days, the root system penetrates to a depth of $2.5 \mathrm{~m}$. In desert animal husbandry, wormwood is one of the best forage plants. $100 \mathrm{~kg}$ of hay contains 18-66 feed units during the growing season. In many pastures, the basis (more than $50 \%$ of the gross stock) of forage is wormwood. On some types of pastures, the yield of wormwood is $0.8-1.0 \mathrm{t} / \mathrm{ha}$.

The created agrophytocenoses using shrub and semi-shrub vegetation reduce the speed of winds, trap snow and protect the soil from deflation, create a milder microclimate in the cenosis and in adjacent areas of pastures. This, in turn, creates more favorable environmental conditions for the growth and formation of a relatively large yield of pasture fodder and the development of other plant species. The use of these methods allows increasing the biodiversity and, accordingly, the fodder reserve of pastures by 2-3 times.

Forest pastures in all ecological zones are a place for seasonal grazing of animals and hay making in designated areas. Most forest pastures are composed of three layers - a mixture of grasses, shrubs, bushes and trees. In the structure of pastures of the Republic there are 2.98 million hectares of hayfields and pastures of which mountainous - $4.3 \%$, alpine $-2.6 \%$ Key problems of forest pasture degradation: irregular and unsystematic grazing of animals, cutting of vegetation for fuel, collection of plant and medicinal raw materials, fires, drought. The main threats to forest pastures:

-reduction of habitats, decrease in the volume of water sources, as well as an increase in the number of grazed animals;

-lack of innovative practices for pasture restoration;

-an increase in the area of degraded pastures; 
-degradation of pastures, deterioration of the state of biotic communities (ecosystems);

-decreased soil fertility, erosion and desiccation;

-aging of forests, decrease in biodiversity;

-illegal and unsystematic felling of shrubs and trees.

In the sustainable management of forest pastures, the participation of the local population in the restoration, protection, protection and rational use of forest resources and mountain pasture ecosystems is important. Raising awareness of forests and the condition of pastures of residents bordering the forest area, consideration of the priority of the environmental factor in planning the use of agricultural land, restoration of pasture landscapes (ecosystems) and their preservation is a vital aspect too.

Moreover, sustainable use of pastures on the basis of regulated livestock grazing and their reproduction (selection of plots for grazing, introduction of pasture rotation, selection of plots for haymaking, improvement of the payment mechanism for grazing and haymaking) plays an important part.

To restore degraded forest pastures, overseeding of semi-shrub vegetation is recommended, such as Ceratoides eversmanniana, Kochia prostrata, Artemisia, Onobrychus chorossanica, Poa bulbosa, Agropyron, Astragalus, medicinal and resource species.

\section{Conclusions}

Restoration of pastures will allow:

-to increase productivity by 2-3 times and, accordingly, increase the profitability of animal husbandry.

-to increase the degree of conservation of biodiversity of vegetation, animals and birds.

-to strengthen the foothill zone slopes of hills prone to water erosion, improve the water regime and preserve the upper fertile layer of the earth.

-to fix and reduce the degree of mobility of sand dunes in the desert zone.

The created plantations will allow the use of pastures in all seasons of the year, increase soil fertility, sequestration of $\mathrm{CO}_{2}-480 \mathrm{~kg}$ per 1 ha, will have a beneficial effect on improving the environment and contribute to the creation of a pasture management system adapted to the conditions of global climate change.

\section{References}

1. L.S. Gaevskaya, Karakul pastures of Central Asia, (FAN, Tashkent, 1971)

2. L.S. Gaevskaya, Karakul Sheep Husbandry Ranges in Central Asia (FAN, Tashkent: 1971)

3. Mukimov T. Uzbekistan - Rangelands and Pasturelands: Problems and Prospects (International Dryland Management Consultant, Adelaide, Australia, and others, NOVA) https://www.novapublishers.com/catalog/product_info.php?products $\mathrm{id}=60416$

4. V.A. Burygin, The Vegetation Cover of Uzbekistan and its Rational Use (FAN, Tashkent, 1976)

5. Guidelines for the geobotanical survey of natural forage lands in Uzbekistan (Science, Tashkent, 1980)

6. N.S. Salmanov, Intra-annual productivity of herbaceous vegetation in sagebrushephemeral rangelands of Uzbekistan Arid Fodder Production (Mehnat, Tashkent, 1986)

7. J.A. Gamon, C.B. Field, D.A. Roberts, S.L. Ustin, R. Valentini, Remote sensing of environment, 44, 2 (1993) 
8. T. Rajabov, B. Mardonov, M. Nasyrov, M. Muminov, T. Mukimov, Journal of Environmental Science and Engineering, 4 (2010).

9. Rajabov T. Ecological assessment of spatio-temporal changes of vegetation in response to biosphere effects in semi-arid rangelands of Uzbekistan. Online Source: http://www. unulrt.is/static/fellows/document/rajabov-t. pdf. Accessed on, 9. (2009)

10. T. Mukimov, UNDP report, project "Land" (Tashkent, 2019)

11. O.I. Morozova, Rangelands Economy in the Karakul Sheep Husbandry of Central Asia ( Mezhdunarodnaya kniga, Moscow, 1946)

12. G. Gintzburger, K.N. Toderich, B.K. Mardonov, M.M. Mahmudov, Experimental Agriculture (Cambridge University Press, UK, 2004)

13. A. Rahmatullaev, Landscapes of ridge Aktau, their use rational economic and protection (FAN, Tashkent, 1991)

14. Kh. Khaydarov, T. Mukimov, B. Islamov, N. Nurullayeva, Biological International Journal of Scientific and Technological Research. 6, 8 (2020)

15. M. Muminov and all, Open Journal of Ecology. 6, 12 (2016)

16. M. Nosyrov, Karnab Chul, Samarkand, Uzbekistan: framework of assessment methodology, Combating Desertification (SUMAMAD), Proceedings of the second international workshop, UNESCO-MAB Drylands Series, 3, Shiraz, Iran, (2003)

17. M. G. Nosirov, M.A. Muminov, T. F. Rajabov, B.K. Mardonov, T. Kh. Mukimov. Science and practice (Zomin nazhr, Tashkent, 2019)

18. T. Farmanov, A. Mukhtorov, T. Mukimov, International Journal of Scientific and Technological Research, 6, 10 (2020)

19. L.A. Nazaryuk, Results and prospects of breeding izen (Kochia) in Central Asia (Samarkand, 1979)

20. M.M. Mahmudov Country Pasture/Forage Resource Profiles, Uzbekistan (2006).

Retrieved 14.Agust, 2009, from

http://www.fao.org/ag/AGP/AGPC/doc/Counprof/Uzbekistan/uzbekistan.htm. 